THE EYE

THE HAND

THE MIND 


\section{The Eye}

the Hand

the Mind

100 Years of the

College Art Association

EDITED BY SUSAN BALL

THE COLLEGE ART ASSOCIATION

New York

and

RUTGERS UNIVERSITY PRESS

New Brunswick, New Jersey, and London 
Unless otherwise noted, the illustrations in this volume have been provided by the owners of the works of art or by the College Art Association. Every effort has been made to contact the copyright holders of all works reproduced in this book. Photographers' names are provided where they have been accessible. All efforts have been made to contact photographers.

This collection copyright (c) 2011 by The College Art Association and Rutgers, The State University of New Jersey

All rights reserved

No part of this book may be reproduced or utilized in any form or by any means, electronic or mechanical, or by any information storage and retrieval system, without written permission from the publisher. Please contact Rutgers University Press, 100 Joyce Kilmer Avenue, Piscataway, NJ 08854-8099. The only exception to this prohibition is "fair use" as defined by U.S. copyright law.

Visit our Web site: http://rutgerspress.rutgers.edu

Printed in China through Four Colour Print Group, Louisville, Kentucky

Library of Congress Cataloging-in-Publication Data

The eye, the hand, the mind : 100 years of the College Art Association / edited by Susan Ball.

p. cm.

Includes bibliographical references and index.

ISBN 978-o-8135-4787-9 (hardcover : alk. paper)

1. College Art Association (U.S.) I. Ball, Susan L.

II. Title: 100 years of the College Art Association. III. Title: One hundred years of the College Art Association.

N11.C575B35 2011

$706^{\prime} .073-\mathrm{dc} 22$

2009052303

A British Cataloging-in-Publication record for this book is available from the British Library. 
Dedicated to three key mentors

ROBERT HERBERT

my dissertation adviser, who stood by me when I decided to abandon the academic career for which he had so generously trained me

ANNE COFFIN HANSON another dissertation reader and CAA president (1972-1974), who recruited me for the job at CAA and

PAUL B. ARNOLD

CAA president (1986-1988), without whose support, friendship, and good counsel I would not have been so well-launched on my twenty-plus-year odyssey at the College Art Association 